\title{
Problema do Provimento de Pessoal das Exatorias Federais
}

\author{
Paulo Coriolano Tunis Viana
}

\section{$P$}

ROSSEGUINDO nos comentários que nos propusemos realizar sôbre a reorganização do sistema arrecadador federal, focalizaremos, hoje, o tema relativo ao provimento do pessoal que tem exercício nas Exatorias Federais.

E' fora de dúvida que em tôda emprêsa, seja privada ou pública, o elemento humano constitui o fator primordial de eficiência, pois que dêle depende a realização dos fins a que o órgão tem em vista, com maior ou menor perfeição, segundo a aptidão e capacidade de que é dotado seu quadro de pessoal.

Com relação às Exatorias Federais, não é demais repetir que o problema relacionado com a lotação do pessoal necessário à execução dos seus serviços, apresenta-se como dos mais importantes e de dificil solução, com tendência a se tornar cada vez mais premente, dado o aumento crescente da arrecadação das rendas públicas por elas efetuada, e criação de novas Exatorias, devendo por isso merecer constante atenção, não sòmente por parte da Administração Fazendária, como também dos órgãos da Administração Federal que têm sob seu encargo o recrutamento, seleção e aperfeiçoamento do pessoal que integra o quadro funcional dêsse importante setor administrativo da Uniấo.

Conforme levantamento procedido pelo extinto Serviço de Coletorias Federais, existiam nas Exatorias, até 1961, os seguintes claros em sua lotação, em números aproximados: 650 , na classe dos Coletores, 550, na de Escrivães, classes essas hoje fundidas na única classe de Exatores, e 100, na classe de Auxiliares de Exatoria, sem se computarem cêrca de 660 Escrivães, que exerciam o cargo em caráter interino.

Com a realização, em fins de ano de 1961, de concurso para o ingresso na carreira de Escrivão de Coletoria, esperava-se que êsse grave problema de insuficiência do pessoal de Exatoria fôsse 
resolvido, pelo menos em parte, com a nomeação de candidatos aprovados, o que infelizmente não ocorreu, tendo sido aproveitado, apenas, um número reduzido dos concursados, nas vagas existentes nos niveis inferiores dessa carreira, resultando de semelhante medida pouco ou nenhum efeito na modificação da situação existente.

Daquela época para cá, o número de vagas nas citadas séries funcionais cresceu consideràvelmente, como era de se esperar, em decorrência de falecimentos, aposentadorias e transferência de carreira dos respectivos titulares, agravando mais ainda o problema, que já então se apresentava de difícil solução, e que ainda hoje perdura como um permanente desafio à boa vontade e capacidade dos dirigentes da Fazenda Nacional.

A principal causa dessa situação anômala, outra não foi senão a demora excessiva na realização do enquadramento definitivo do pessoal do Ministério da Fazenda, que só agora foi concluído, uma vez que sòmente após ser consumada essa providência, seria possível a determinação do número total de vagas existentes em todos os niveis das classes de Coletor e Escrivão, atualmente unificadas, como dissemos, na de Exator e Auxiliar de Exatoria, de modo a se poder conhecer o número exato de vagas do nível inicial de cada uma dessas séries de classes, depois de preenchidas as vagas verificadas, com o enquadramento, nos níveis superiores.

Entrementes, como resultado de estudos procedidos pelo referido Serviço de Coletorias Federais, foi proposta, em 1962, a ampliação do quadro de Exatores e Auxiliares de Exatoria, face à evidência de que o número dêsses servidores, fixado com a vigência da Lei $n^{2} 1.293$, de 27-12-950, não mais satisfazia as necessidades reais das Exatorias, que tiveram seus serviços sensivelmente aumentados com o crescimento vegetativo da arrecadação e, sobretudo com a posterior criação de novas dessas estações arrecadadoras, em número de algumas centenas, sem a concomitante criação dos correspondentes cargos de servidores, ocasionando, assim, um desfalque substancial na lotação das Exatorias existentes, que tiveram de ceder parte de seus funcionários, deslocados para servirem nos novos órgãos criados, datando, dai, o desequilibrio que tanto vem perturbando o normal funcionamento dêsse setor fazendário, mantido à custa da solicitude e dedicação do pessoal remanescente, que nêle atua.

Baseado em dados objetivos, o aumento então proposto do número de cargos dessas carreiras, de modo a atender, satisfatòriamente, o regular funcionamento das 2.067 Exatorias, dis- 
seminadas por todo o território nacional, àquela época criadas, instaladas e por instalar, consubstanciava-se no seguinte quadro:

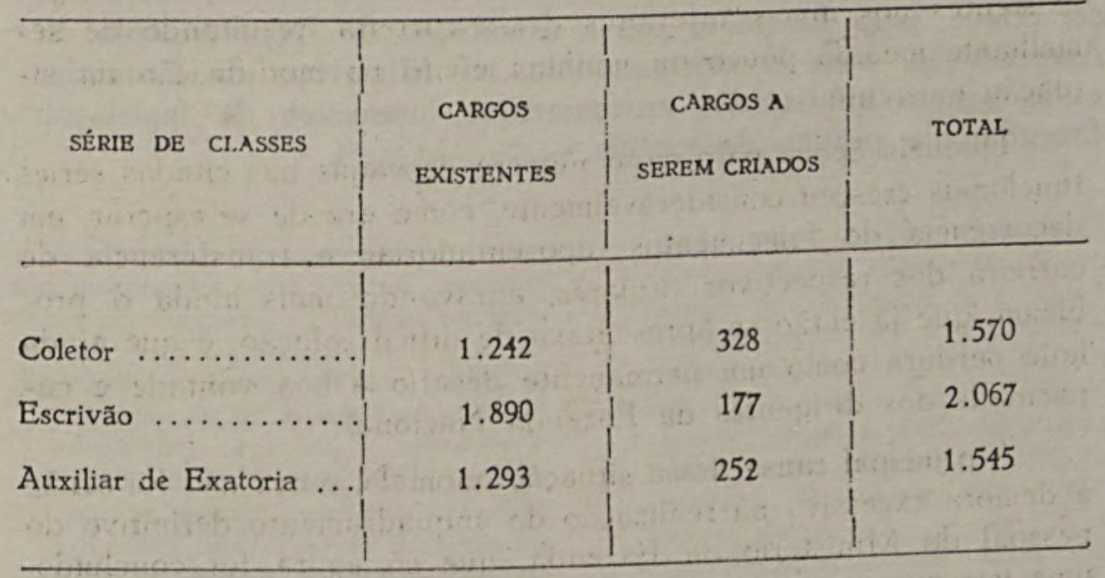

Acolhendo essa proposta, o Poder Executivo encaminhou ao Legislativo projeto de lei, que tomou, no Congresso, o $\mathrm{n}^{\circ} 4.009$, de 1962, dispondo sôbre a ampliação do quadro de pessoal de Exatoria, projeto êste que, infelizmente, ainda não mereceu a apreciação daquela Casa Legislativa.

Decorrido todo êsse tempo, sem que uma tal medida, de tão grande alcance para a normalização do aparelho arrecadador federal, tenha sido resolvida, é de se indagar, por que razão não se aplica a êste caso, o disposto no artigo $4^{\circ}$ do Ato Institucional, que estabelece o prazo máximo de trinta $(30)$ dias, para a apreciação, em cada uma das Casas do Congresso Nacional, de projeto oriundo do Poder Executivo?

Antes de finalizar estas breves considerações sôbre o problema do pessoal das Exatorias Federais, cumpre lembrar que a lotação dessas repartições arrecadadoras estará incompleta, se de seu quadro funcional não integrar a série de classes de Serventes, como determina o artigo 28 da já citada Lei $n^{\circ} 1.293-50$, devendo o provimento dêsses servidores beneficiar, pelo menos, as Exatorias de maior movimento, pois não se justifica que os trabalhos próprios dessa categoria de funcionários possam ser realizados pelo Exator ou pelo Auxiliar de Exatoria, sem que disto não resulte perturbações na boa ordem dos serviços a cargo dêsses órgãos fazendários.

Mencionaremos, por fim, outra providência que, certamente, deverá produzir benéficos resultados para o aprimoramento téc- 
nico dos servidores de Exatoria, qual seja a da criação e manutenção de cursos de preparação e treinamento dêsses funcionários e candidatos ao ingresso nessa carreira, podendo, inclusive, ser criada, para funcionar sob a orientação do Departamento de Arrecadação, uma Exatoria-modêlo, no Ministério da Fazenda, onde seriam ministrados ensinamentos intensivos de legislação fazendária e prática de serviço. 